\title{
True Believers? - Sincerity and Article 9 of the European Convention on Human Rights
}

\author{
Tim Wolff*
}

\begin{abstract}
Sincerity of belief as a condition for the protection of Article 9 of the European Convention on Human Rights - Three types of insincerity in the context of freedom of belief - Parody religions - Fraudulent religions - Conceptual linkage between insincerity and ulterior motive - Insincerity defined as demanding to practise one's 'belief' while solely having an ulterior motive - Circumstances that should not be considered evidence of insincerity: implausible manifestations, inconsistency with co-believers - Circumstances that should be considered evidence of insincerity: obvious unseriousness, ignorance, personal inconsistency Comparison to rejected and accepted forms of evidence of insincerity in the case law of the European Court of Human Rights - Burden of proof in the case law of the European Court of Human Rights.
\end{abstract}

\section{INTRODUCTION}

In jurisdictions where a right to freedom of religion or belief (hereafter, freedom of belief) is enshrined in law, courts must sometimes determine whether individuals who invoke said right are being honest about what they claim to believe. Determining (in)sincerity in this context is a delicate matter, and there is no consensus as to which types of considerations for doing so are legitimate.

This article's first objective is to outline what I take to be the most defensible approach to this matter. The central questions here are: which types of circumstance raise legitimate doubts about sincerity? And what evidentiary role should these credibility-undermining circumstances play in the judicial fact-finding

*Assistant professor, University of Amsterdam, Paul Scholten Centre for Jurisprudence. I am grateful to the editor and reviewers for helpful comments on the initial text of this paper.

European Constitutional Law Review, 17: 259-286, 2021

(C) The Author(s), 2021. Published by Cambridge University Press on behalf of European Constitutional Law Review. This is an Open Access article, distributed under the terms of the Creative Commons Attribution licence (http://creativecommons.org/licenses/by/4.0/), which permits unrestricted re-use, distribution, and reproduction in any medium, provided the original work is properly cited. doi:10.1017/S1574019621000171 
process? To provide some background to these questions, the second and third sections are devoted to a conceptual analysis of sincerity in the context of freedom of belief. The second section offers an account of the three ways an individual can be insincere about belief, while the third section explores the conceptual linkage between sincerity and ulterior motive: insincerity occurs when an individual demands to practise her 'belief' while solely having an ulterior motive. The fourth section discusses which circumstances may be taken as evidence of insincerity, so understood. Five candidates are considered. The first two, implausible manifestation' and 'inconsistency with beliefs of co-believers', are rejected. The remaining three, 'obvious unseriousness of the belief system', 'ignorance regarding the belief system', and 'personal inconsistency', should be seen as providing legitimate evidence of insincerity, or so I argue. Some of these circumstances (e.g. personal inconsistency) are emphasised by almost all writers on the subject, which allows me to draw on their work. Others have received little or no scholarly attention, which impels me to develop some tentative ideas of my own. The fifth section provides a short discussion of burden of proof.

This article's second objective concerns the case law on sincerity. Most of the literature focuses on the ways in which American and British courts assess (in) sincerity of belief. The article turns the spotlight onto the European Court of Human Rights (hereafter: the Court). With respect to Article 9 of the European Convention on Human Rights (hereafter: the Convention), a case law guide on the Court's website states that 'domestic authorities are not justified in casting doubt on the sincerity of the beliefs which an individual claims to hold without supporting their position with solid, cogent evidence'. ${ }^{1}$ Given this strong admonition directed at the Contracting States, it is worth examining how the Court goes about assessing (in)sincerity in Article 9 cases (or, rather, how it supervises the way states perform this task).

The article's strategy for connecting the two objectives is as follows. In the discussion of each candidate for credibility-undermining circumstance, an account is included of its role in pertinent case law. Some circumstances have repeatedly been addressed by the Court, and the article attempts to determine whether it has done so in a consistent and persuasive manner. With respect to some other circumstances, on the other hand, examining the case law yields scarce results, owing to the fact that the Court has not yet had the opportunity to address them. (For example, to my knowledge, the Court has never decided on a case that involved a parody religion.) In these cases a more speculative account is given, by extrapolating or analogising the case law on adjacent subjects.

\footnotetext{
${ }^{1}$ Directorate of the Jurisconsult, 'Guide on Article 9 of the European Convention on Human Rights' (2020) 〈www.echr.coe.int/Documents/Guide_Art_9_ENG.pdf), visited 15 June 2021, p. 12 .
} 


\section{A TALE OF THREE INSINCERITIES}

Liberal democracies guarantee some version of freedom of belief, where 'belief' denotes both 'belief systems' and 'individual beliefs belonging to belief systems'. For the purposes of this article and in keeping with the case law of the Court, the concept 'belief system' includes religious as well as non-religious belief systems such as pacifism and veganism. Freedom of belief includes the right to practise one's beliefs. If someone invokes her right to practise her belief before a court of law, the court must be satisfied that the following three conditions are met:

- The Belief System Condition: the belief system of the person concerned must be a belief system in the relevant legal sense. (For instance, is Zoroastrianism a belief system under our jurisdiction's version of freedom of belief?)

- The Manifestation Condition: the practice must be a manifestation of the belief system. (Does the practice have a sufficiently close connection to Zoroastrianism? For instance, is ritual exposure of a deceased person prescribed, advised, suggested, or implied by Zoroastrianism?)

- The Sincerity Condition: the person must truly believe what she claims to believe. (Is this person truly an adherent of Zoroastrianism and does she truly believe ritual exposure is a manifestation of it?)

The most logical course is to assess these conditions in the stated order. The most fundamental question is whether there even is a belief system in the relevant sense. If there is, the next question is whether the practice at issue is in some minimally plausible way connected to that belief system. If so, only then does it make sense to ascertain that this person really does adhere to and base the practice upon said belief system. However, as will become clear shortly, in some jurisdictions and in some circumstances, the Sincerity Condition is baked into the Belief System Condition, which somewhat complicates this sequence.

For now, let us take a closer look at the Sincerity Condition. There are three ways one can fail to meet it. In other words, there are three types of insincerity: ${ }^{2}$

(a) insincerity about the existence of a belief system (fake belief systems);

(b) insincerity about one's adherence to a belief system (fake adherents);

(c) insincerity about a practice being a manifestation of a belief system (fake practitioners).

\footnotetext{
${ }^{2}$ Insincerely invoking freedom of belief is an offence of sorts. Hence the focus in this article (and in the literature more generally) is on evidence of insincerity as opposed to evidence of sincerity. See also the section on burden of proof below.
} 


\section{Insincerity about the existence of a belief system (fake belief systems)}

As the term indicates, a belief system is a set of connected propositions that one or more persons believe to be true. (To some minimal degree. For example, one can disbelieve the literal resurrection of Christ and still be a Christian. ${ }^{3}$ Moreover, it is quite common for a genuine believer to be ignorant of many doctrinal aspects of her belief system and to practise it in a mostly ritualistic or communitarian fashion. ${ }^{4}$ For instance, she may be unable to cite the Ten Commandments and be a devout Christian nonetheless.) A set of propositions that is believed by no one but presented as a belief system is not an actual but rather a fictional or fake belief system; it does not actually exist qua belief system. If a person claims that a 'belief system' which is in fact fake really exists, that there are people, including herself, who really believe it to be true, she is being insincere. For example, it is highly unlikely that anyone truly believes the Flying Spaghetti Monster exists, but there have been many legal proceedings in various countries where Pastafarianism (the 'belief system' that holds the Flying Spaghetti Monster at its centre) is invoked as grounds for a religious exemption. To the extent that these litigants claim they really believe in Pastafarianism's tenets, they are most likely dishonest. The whole matter is uncontroversially a parody. Most 'Pastafarians' are likely sincere about something, namely the parody's message, which is that it is morally outrageous that some people receive legal benefits that others do not, only because they hold ridiculous religious beliefs (in the eyes of the 'Pastafarians'). But they are not sincere about the existence of Pastafarianism as a genuine belief system.

Other examples of fake belief systems aside from parodies are fraudulent belief systems: religious or philosophical 'views' that are made up solely for the purpose of gaining some benefit or avoiding some burden. The Monastic Order of the Sisters of Walburga, for example, was invented by the management of a sex club in Amsterdam to fend off police checks. (At the time, it was illegal for the police to search places of worship during religious services.) Another example is the U.S.based Church of Cognizance, allegedly invented by Mary and Dan Quaintance to avoid criminal conviction for the possession and trafficking of marijuana. To the extent that 'adherents' of fraudulent belief systems claim to follow a genuine belief system - that is, a set of propositions actual people believe to be true - they are insincere about its existence. This insincerity is structurally analogous to the

${ }^{3}$ J.T. Noonan, Jr., 'How Sincere Do You Have to Be to Be Religious?', 713 University of Illinois Law Review (1988) (discussing the difference between literal and metaphorical truth); K. Greenawalt, Religion and the Constitution, Volume 1: Free Exercise and Fairness (Princeton University Press 2006) p. 114 (discussing the example of Christian ministers who do not literally believe certain tenets of the Christian faith).

${ }^{4}$ C. LaBorde, Liberalism's Religion (Harvard College 2017) p. 66. 
phenomenon of parody belief systems such as Pastafarianism. The difference is the nature of the motive. With parody belief systems, the motive is the making of a political point, whereas with fraudulent belief systems, the motive is the gaining of some material advantage.

What if a 'belief system' that was invented for fraudulent reasons is subsequently believed by some or even many people? For instance, it has plausibly been argued that L. Ron Hubbard was a swindler who invented the Church of Scientology as an elaborate way to separate gullible people from their money. ${ }^{5}$ However, most Scientologists are clearly true believers, which means Scientology actually does exist as a belief system. It involves a set of connected propositions that some - in the case of Scientology: many - individuals believe to be true. Accordingly, and rightly, Scientology has been recognised by the Court as a belief system within the meaning of Article 9. ${ }^{6}$ The people who are (or were) involved in Scientology for purely fraudulent reasons (such as Hubbard, presumably) on the other hand, are what may be called fake adherents (see the next subsection).

There is a link between insincerity about the existence of a belief system (Sincerity Condition) on the one hand, and (failure to satisfy) the Belief System Condition on the other. Depending on the jurisdiction and the circumstances of the case, the two can be intertwined. In the case law of the Court, for example, sincerity (or some equivalent concept, such as 'seriousness') is an element of the legal definition of 'belief system' (or some equivalent concept). Take Pastafarianism. The fact that no one really believes in the Flying Spaghetti Monster (insincerity about the existence of a belief system) may be considered an important reason to conclude that there is no belief system in the legal sense (Belief System Condition). In a Pastafarianism case in the Netherlands, this is exactly what the appellate court argued. Because the 'belief system' of Pastafarianism is not serious, the court stated, there is no belief system in the relevant legal sense. ${ }^{7}$ The appellate court applied the criterion of seriousness because, as is well known, seriousness is one of the four criteria for the Belief System Condition that the Court formulated in Campbell and Cosans v The United Kingdom ('a certain level of seriousness, cohesion, cogency, importance') ${ }^{8}$ and has maintained ever since. Even though Campbell and Cosans did not concern a parody belief system, the Court appears to have considered that no unserious

${ }^{5}$ For a comprehensive account, see L. Wright, Going Clear: Scientology, Hollywood, and the Prison of Belief (Random House 2013).

${ }^{6}$ ECtHR 1 October 2009, No. 76836/01, Kymlia and others v Russia; ECtHR 5 April 2007, No. 18147/02, Church of Scientology of Moscow v Russia. It should be noted that the Court in these cases deferred to the judgment of the national authorities and offered no substantive judgment as to whether Scientology meets the criteria for 'religion' within the meaning of Art. 9.

${ }^{7}$ AbRvS 15 August 2018, ECLI:NL:RVS:2018:2715.

${ }^{8}$ ECtHR 25 February 1982, No. 7511/76, Campbell and Cosans v The United Kingdom s. 36. 
belief system should be considered a belief within the meaning of Article 9. This makes sense: lack of seriousness entails that the professed belief system is not genuinely endorsed by anyone; it is only insincerely 'adhered to'. That is to say, there is no real belief system. And if there is no actual belief system, there should be no belief system legally speaking.

As was noted earlier, this may complicate the normal sequence of first assessing the Belief System Condition, then the Manifestation Condition, and finally the Sincerity Condition. The reason should now be clear. If seriousness is seen as a requirement for belief systems (as in the case law of the Court) and in a given case seriousness is lacking, as with a parody, then the first type of insincerity (insincerity about the existence of a belief system) is baked into the test for the Belief System Condition. In such - fairly special - circumstances, the Belief System Condition and the Sincerity Condition overlap and their assessment takes place, as it were, simultaneously.

\section{Insincerity about one's adherence to a belief system (fake adherents)}

The second type of insincerity concerns feigned adherence to an existing belief system. If an existing belief system is a set of connected propositions that at least some people believe to be true, a fake adherent is someone who pretends to be one of those people but is actually not. A useful example is the case Kosteski v The Former Yugoslav Republic of Macedonia, ${ }^{9}$ which involved a man who falsely claimed to be a Muslim and demanded a day off from work on an Islamic holiday in a jurisdiction that guarantees paid leave on Islamic holidays for Muslim employees. ${ }^{10}$ It is of course uncontroversial that Islam is a belief system in the relevant legal sense (Belief System Condition). If the date in question is a genuine Islamic holiday, the Manifestation Condition is also met - celebrating it is a manifestation of the religion. But of course the Sincerity Condition is clearly not met because the man was not really a follower of Islam.

In short, there is a genuine belief system, but the individual in question is just not one of its adherents. I suspect this is the most common form of insincerity. A subset of prison cases fall within this category. These involve prisoners who feign adherence to a legally well-established belief system in order to attain some (often dietary or sartorial) exemption or privilege. ${ }^{11}$ Also within this category are cases in

${ }^{9}$ ECtHR 13 April 2006, No. 55170/00, Kosteski v The Former Yugoslav Republic of Macedonia.

${ }^{10}$ For the purposes of this discussion, it is assumed that Kosteski's claim was false. Strictly speaking, this is not a hundred per cent certain. What is known is that there was much circumstantial evidence pointing to insincerity and that he failed to provide evidence for his claim of sincerity.

${ }^{11}$ Commission decision 10 February 1993, No. 18187/91, Wv The United Kingdom; ECtHR 31 January 2012, No. 35021/05, Kovalkovs v Latvia; ECtHR 17 December 2013, No. 14150/08, Vartic v Romania. 
which asylum seekers falsely claim to be adherents of a religion whose members are persecuted in their country of origin. ${ }^{12}$

\section{Insincerity about a practice being a manifestation of a belief system (fake practitioners)}

This type concerns insincerity about a practice being a manifestation of an existing belief system. The individual in question claims that a practice is a manifestation of her belief system, but she does not truly believe this. (Even though others might. For instance, many Muslims do not believe female genital mutilation is an Islamic practice, but some Muslims feel certain it is.) With respect to that particular practice, she is a fake practitioner. (She may of course be a genuine practitioner with respect to other practices associated with her belief system.) An example would be individuals who are genuinely religious, and who furthermore do not believe they have religious reasons to refuse mandatory vaccinations, but decline to have their children vaccinated, while insincerely citing 'religious reasons'. (Let us suppose a rule-plus-exemption system is in place.) What these individuals are insincere about is their 'belief' that the practice of non-vaccination is a manifestation of their religion.

In this example, the 'manifestation' might be endorsed by some or even many adherents of the belief system, just not by the adherent in question (the claimant). A different possibility is that the purported manifestation is very unusual or even idiosyncratic. In $D$ v France, ${ }^{13}$ a practising Jew refused to hand over the so-called get (a letter of repudiation required for Jewish-Orthodox religious divorce) to his ex-wife subsequent to their civil divorce. He claimed that, since he was a member of the Cohen family, he was according to Mosaic law not allowed to marry a divorced woman, and he wanted to preserve the option of remarrying his ex-wife. He also claimed that his refusal was a manifestation of his religion. It is unclear from the facts of the case whether or not the man honestly believed the refusal was a manifestation of his belief system. (His self-proclaimed ulterior motive provides reason for some doubt.) The Court held that the refusal was not a manifestation of Judaism and left it at that, so the sincerity question was never directly addressed. However, and this is the pertinent point for present purposes, if the appellant was insincere on this score, the case would become an example of type (c) insincerity.

\footnotetext{
${ }^{12}$ For examples, see M. Kagan, 'Is Truth in the Eye of the Beholder? Objective Credibility Assessment in Refugee Status Determination', 17(3) Georgetown Immigration Law Journal (2003) p. 367; S. Norman, 'Assessing the Credibility of Refugee Applicants: A Judicial Perspective', 19(2) International Journal of Refugee Law (2007) p. 273; J.A. Sweeney, 'Credibility, Proof and Refugee Law', 21(4) International Journal of Refugee Law (2009) p.700.

${ }^{13}$ Commission decision 6 December 1983, No. 10180/82, D v France.
} 
Lest there be misunderstanding: this type of insincerity is connected but not identical to (failure to satisfy) the Manifestation Condition. With the Manifestation Condition, the question is: is the practice a manifestation of the belief system in the relevant legal sense? (I.e., is there a sufficiently plausible connection between belief system and purported manifestation?) With type (c) insincerity, on the other hand, the question is: supposing the practice is a manifestation in the relevant legal sense, does this individual, as a matter of fact, truly believe that the practice is a manifestation of the belief system?

\section{INSINCERITY AND 'ULTERIOR-MOTIVE-SOLELY': TWO SIDES OF THE SAME COIN}

How should courts determine whether an individual has been insincere in one or more of the three ways described above? This question cannot properly be answered without a discussion of the matter of motive - or rather, ulterior motive. There is a close conceptual link between insincerity and ulterior motive. That is, all three forms of insincerity entail a motive other than the wish to practise one's belief. It does not work the other way around: the presence of an ulterior motive does not necessarily entail insincerity. Let me explain by sketching three motive-related possibilities that are present whenever an individual demands to practise his belief:

- He is telling the truth; he holds the belief in question, and that is his sole motive; (For instance, a conscientious objector to military service has only one motive for refusing to serve in the military, which is incompatibility with his belief system.)

- He is telling the truth; he holds the belief in question, but he also has an ulterior motive; (For instance, a religious person who wishes to grow a beard for two reasons: (1) the belief that his religion requires it; and (2) the fact that it makes him look handsome.)

- He is lying; he solely has an ulterior motive. (For instance, a fake adherent of a religion, who has only one motive for his deceit: getting paid leave from work on religious holidays.)

The first possibility demonstrates that the mere presence of a likely ulterior motive is not enough to establish insincerity. Surely there are several possible and likely motives for wanting to avoid military service, but that does not imply that conscientious objector claims are necessarily insincere. The second possibility illustrates what I have just noted: that not even the presence of an ulterior motive necessarily entails insincerity. In other words, there may be 'innocent' ulterior motives. ${ }^{14}$ The fact that someone grows a beard partly because he thinks doing so makes him look

\footnotetext{
${ }^{14}$ N.S. Chapman, 'Adjudicating Religious Sincerity', 92 Washington Law Review (2017) p. 1185 at p. 1233.
} 
handsome is wholly compatible with his believing that his belief system commands it. ${ }^{15}$ The third possibility illustrates that insincerity always involves the presence of an ulterior motive and the absence of a legitimate motive. Let us call this aspect of insincerity ulterior-motive-solely.

Ulterior-motive-solely is a corollary of all three forms of insincerity. This connects to two important points. First, the fact that insincerity and ulteriormotive-solely are two sides of the same coin presents positive news for claimants in cases in which there is no sufficiently likely ulterior motive: the likelihood of insincerity in such cases is correspondingly small. Skugar and others $\mathrm{v}$ Russia ${ }^{16}$ provides an example. The case involved members of the Russian Orthodox Church who demanded that their government-assigned taxpayer's numbers be cancelled on the grounds that, according to the Bible, such numbers are a mark of the Antichrist. In other words, they demanded an exemption from the general rule that every citizen be assigned a taxpayer's number. Unlike with rules that require vaccination, military service, or attendance at work on religious holidays and rules that prohibit the ingesting of certain substances, there is no plausible upside to receiving an exemption from the taxpayer's number rule. What advantage might these claimants possibly be 'really' after? If anything, an exemption would be liable to create additional administrative hassle and aggravation. ${ }^{17}$ The Court was therefore correct in stating that there was no indication of insincerity on the part of the applicants' ${ }^{18}$

In S.A.S. v France, the Muslim claimant wished to wear a full face veil in public because she claimed it was part of her religion. Here, too, it is difficult to imagine a motive other than the religious one, especially a motive worthy of going to the lengths of bringing a case before the Court. ${ }^{19}$ Thus, I would agree with the Court's conclusion that the woman should not be required to prove she is a practising

${ }^{15} C f W_{\mathrm{v}}$ The United Kingdom, supra n. 11. In this case, the Commission seemed to believe there was an innocent ulterior motive. It involved a purportedly vegan prisoner who refused to work in the prison print shop because doing so would entail working with animal-tested products. The government alleged that his real motive was the wish to work outdoors, but the Commission found 'that a motive of his refusal, though apparently not the only motive, was his Vegan beliefs' (para. 1, emphasis added).

${ }^{16}$ ECtHR 3 December 2009, No. 40010/04, Skugar and others v Russia.

${ }^{17}$ In theory, they could have had an ulterior motive, such as a peculiar wish to be involved in litigation or to inconvenience the government. However, these motives are so improbable that they may reasonably be disregarded.

${ }^{18}$ Unfortunately, the Court did not explicitly state that the absence of a likely ulterior motive was a reason for this conclusion, so we cannot be sure that it was.

${ }^{19}$ Difficult, but not impossible. The woman could have been insincere in that her real reason for wearing the full face veil might have been a wish to hide what she considered to be revolting facial features, say. Again, given the unlikelihood of such ulterior motives, it seems a safe bet to disregard the possibility. 
Muslim. Strangely, the Court's stated reason for this was not the unlikelihood of any ulterior motive, but rather the fact that 'there is no doubt that [wearing the full face veil] is, for certain Muslim women, a form of practical observance and can be seen as a "practice" within the meaning of Article 9'. ${ }^{20}$ It is difficult to see why this point is pertinent to an assessment of sincerity. ${ }^{21}$ The fact that, for certain women, the full face veil is a manifestation of their belief system says little, ceteris paribus, about both the genuineness of this woman's adherence to Islam and the genuineness of her belief that the full face veil is part of Islam. ${ }^{22}$ The Court should have explained that it was highly unlikely that the woman had a reason for wanting to cover her face other than the religious one she offered, and that it therefore had no reason to doubt her sincerity. ${ }^{23}$

What about situations - and this is the second point - where there is a sufficiently likely ulterior motive? As I have noted, the mere presence of a potential ulterior motive does not entail insincerity, and neither does the presence of an actual ulterior motive (since innocent ulterior motives may be present). The only circumstance that necessarily entails insincerity is what I have called ulteriormotive-solely - that is, the presence of an actual ulterior motive combined with the absence of a legitimate motive. Indeed, demanding to practise one's 'belief' while solely having an ulterior motive is the very definition of insincerity. But the difficulty for courts is that this concerns a mental state. Similar to other mental states, such as 'intent' and 'knowledge', it is not directly observable and may only be surmised indirectly (i.e. circumstantially). Thus, ulterior-motive-solely is not a circumstance that can be observed and subsequently serve as proof of insincerity, as several theorists seem to claim. ${ }^{24}$ Rather, it is the case that insincerity and ulterior-motive-solely are aspects of the same non-observable mental state one that may only be surmised on the basis of circumstances that are observable.

\footnotetext{
${ }^{20}$ ECtHR 1 July 2014, No. 43835/11, S.A.S. v France para. 56.

${ }^{21} \mathrm{~A}$. Su, 'Judging Religious Sincerity', 5 Oxford Journal of Law and Religion (2016) p. 42 (criticising the tendency to infer sincerity from the manifestation's plausibility).

${ }^{22}$ However, see Greenawalt, supra n. 3, p. 122 (arguing that, if a claimant is a sincere member of a religious group, she should be able to engage in its practices - presumably even if engaging in those practices is made possible by exemptions - whatever her particular opinion may be about said

${ }^{23}$ Cf Greenawalt, supra n. 3, p. 122-123 ('A finding that a claimant is sincere should be easy if one cannot discern any secular advantage from a person's engaging in the behavior she asserts is part of her religious exercise'); B. Adams and C. Barmore, 'Questioning Sincerity: The Role of The Courts After Hobby Lobby', 59 Stanford Law Review Online (2014) p. 61 (arguing that relevant U.S. case law indicates that 'where there is a financial or otherwise self-interested motive to lie about a religious belief, courts are willing and able to evaluate sincerity').

${ }^{24}$ Adams and Barmore, supra n. 23, p. 62-63. Chapman, supra n. 14, p. 1231-1234. K. Loewentheil and E. Reiner Platt, 'In Defense of the Sincerity Test', in K. Vallier and M. Weber (eds.), Religious Exemptions (Oxford University Press 2018) p. 255-258.
} practices). 
The question then becomes: which might these observable, credibility-undermining circumstances be? This is the topic of the next section.

\section{FIVE CANDIDATES FOR CREDIBILITY-UNDERMINING CIRCUMSTANCE}

Credibility-undermining circumstances are states of affairs that give rise to legitimate suspicions of insincerity and may legitimately be employed in proving it. I will discuss five candidates for such circumstances. The first two will be rejected, the remaining three will be accepted as legitimate. The candidates are:

(1) implausible 'manifestation';

(2) inconsistency with beliefs of co-believers;

(3) obvious unseriousness of the belief system;

(4) ignorance regarding the belief system;

(5) personal inconsistency.

\section{Implausible 'manifestation'}

It is uncontroversial that courts may and should assess what I have called the Belief System Condition. The religious or philosophical view put forward by the claimant must be of the right kind to fall under the protection of freedom of belief. Accordingly, courts submit even firmly held beliefs to scrutiny. For instance, in Gough v The United Kingdom, the applicant adhered to a strong belief in the inoffensiveness of the human body, which he expressed by taking very long walks through the countryside naked. The Court held that he had not shown that 'his beliefs met the necessary requirements of cogency, seriousness, cohesion and importance to fall within the scope of Article 9 of the Convention'. ${ }^{25}$

Should courts engage likewise with the Manifestation Condition? This is more controversial. Reluctance to enter into doctrinal debates about what various belief systems prescribe, advise, suggest, or imply in the way of behaviour is prevalent in both the U.S. and Europe. This reluctance seems to be based both on the idea that courts lack competence in this area (especially in multicultural societies) and the idea that belief systems are increasingly fluid and subjective. The legal scholar Anna Su calls this 'the subjective turn'. ${ }^{26}$ Nathan Chapman, in an insightful article on religious sincerity, seems to advocate even more than reluctance. He argues, or seems to argue, that courts may never engage in determining whether a practice has a sufficiently close and plausible connection to a belief system. ${ }^{27}$ He sees this

\footnotetext{
${ }^{25}$ ECtHR 28 October 2014, No. 49327/11, Gough v The United Kingdom para. 188.

${ }^{26} \mathrm{Su}$, supra n. 21, p. 30.

${ }^{27}$ Chapman, supra n. 14, p. 1227.
} 
as part of the more general 'no-orthodoxy principle'. He also argues that this view is mainstream among American judges and scholars. ${ }^{28} \mathrm{An}$ implication of it is that courts should never infer type (c) insincerity (about a practice being a manifestation of a belief system) from the implausibility of a purported manifestation. Such an inference would require courts to do exactly what the no-orthodoxy principle forbids: evaluate the plausibility of purported manifestations.

There are really two questions here:

- Should courts assess manifestation plausibility?

- If the answer to the first question is 'yes', and if a court arrives at the conclusion that some practice is not sufficiently plausibly a manifestation of the belief system, should insincerity then be inferred from this implausibility?

I believe the answer to the first question is 'yes', and the answer to the second question is 'no, both for principled and practical reasons'.

Let us start with the first question. Chapman and other proponents of the no-orthodoxy principle are surely correct in believing that courts ought to be wary of engaging in doctrinal disputes. Courts are not necessarily competent theologians, and they should largely leave doctrinal questions to ecclesiastical institutions (or secular equivalents) and individual believers. But the notion that courts should not at all be in the business of assessing purported manifestations is too absolutist. Admittedly, it would certainly be unacceptable for a court to claim that declining to eat cheese is not a manifestation of veganism (which the Court has recognised as a 'belief' within the meaning of Article 9), because it evidently is. It would be equally unacceptable for a court to take sides in matters that are highly contentious within the belief system itself, such as the religious dispute within Islam about whether or not the wearing of the hijab is compulsory. That is a doctrinal dispute if ever there was one. But there are also cases that clearly fall outside the scope of plausible manifestations. Suppose someone says 'I am a Catholic and therefore I am required to perform ten cartwheels every two hours. My employer has a legal obligation to accommodate this religious practice of mine at our office building by reserving sufficiently large, empty rooms for this purpose'. Surely courts ought to be able to argue that on no minimally plausible understanding of Catholicism is the described practice one of its manifestations. ${ }^{29}$

\footnotetext{
${ }^{28}$ Although the U.S. Supreme Court has stated in Thomas v Review Bd. F the Ind. Emp't Sec. Div., 450 U.S. 707 (1981) 715-716 that '[O]ne can, of course, imagine an asserted claim so bizarre, so clearly nonreligious in motivation, as not to be entitled to protection under the Free Exercise Clause'.

${ }^{29}$ Cf D. Miller, 'Majorities and Minarets: Religious Freedom and Public Space', 46(2) British Journal of Political Science (2016) p. 437 (going even further and arguing that freedom of religion should only extend to practices that are required by the religion in question according to holy texts and/or religious leaders).
} 
Chapman, on the other hand, seems to argue that this type of inquiry would constitute judicial involvement in a doctrinal dispute:

Whether [a belief concerning a religious practice] accurately reflects the best understanding of the religion would require the government to determine the best understanding of that religion, something the no-orthodoxy principle flatly prohibits. So too with whether the claimant's moral reasoning, or conscientious judgment on the basis of that reasoning reflects either the community's beliefs or an accurate mode of moral reasoning. Some may find it unfortunate ... that the no-orthodoxy principle tolerates religious atomism. But it does. With respect to religious accuracy - including accuracy about what the claimant's religion requires - each person is an island. ${ }^{30}$

The law should indeed tolerate religious atomism. Unusual practices may merit legal protection. But what does not follow is 'anything goes'. If a practice has no minimally plausible connection to the belief system (e.g. the cartwheels example), it really is unclear why courts should not dismiss the claim in question. ${ }^{31}$ The Court certainly feels authorised to do so - even, interestingly, in cases in which the practice is not evidently outside the scope of plausible manifestations. In Skugar, for example, the Court expresses no doubts about the legitimacy of judicial assessment of manifestation plausibility. It repeats a phrase it has used in many cases:

The term 'practice' in Article 9 does not cover any act which is motivated or influenced by a religion or belief. When the actions of individuals do not actually express the belief concerned, they cannot be considered to be as such protected by Article $9 \$ 1$, even when they are motivated or influenced by it. ${ }^{32}$

\footnotetext{
${ }^{30}$ Chapman, supra n. 14 , p. 1227.

${ }^{31}$ Perhaps even Chapman would, upon reflection, agree with this point. His example of a seemingly outlandish practice involves an individual who claims his religion forbids him from shaving his beard, but '[n]o one else who shares his religious beliefs agrees with him. And there appears to be no ordinary logic that would lead someone to conclude [ ...] that the religion forbids an adherent from shaving' (p. 1226). This instance may indeed constitute religious atomism, but and this is my point - even in Chapman's telling, the practice is not altogether disconnected from the underlying belief system. He writes: 'Suppose the reason this particular adherent believes his religion forbids beard-shaving is because its holy texts forbid touching another person's hair trimmings, and from this prohibition the adherent has determined that he cannot make it easier for someone else to violate this prohibition by shaving his beard and sending the trimmings on their merry way' (p. 1227, emphasis in original).

${ }^{32}$ Skugar v Russia, supra n. 16.
} 
The Court has demonstrated its willingness to assess manifestation plausibility in a range of cases, ${ }^{33}$ and in doing so it is not, as Chapman would have it, engaging in a determination of whether the practices accurately reflect the best understandings of the religions involved. It is merely assessing whether there is a minimally plausible connection. ${ }^{34}$ Deciding such quandaries is precisely what judges are meant to do, I would argue.

Which brings us to the second question: if a court arrives at the conclusion that some practice is not sufficiently plausibly a manifestation of the belief system, should insincerity then be inferred from this implausibility? The answer is no. First of all for the principled reason that the absence, in the Court's words, of a 'sufficiently close and direct nexus' between the underlying belief system and the purported manifestation is not dispositive of insincerity on the part of the claimant. After all, the claimant may genuinely believe that there is such a nexus. She may simply sincerely disagree with the assessment of the court.

In a way, however, this matter is academic, which should be clear if we turn to the second, more practical reason why the answer is no: if and when it is determined that a practice is insufficiently plausibly connected to a belief system, the question of sincerity has become moot. Take $D \mathrm{v}$ France. Once it is decided that a refusal to hand over the get is not a manifestation of the claimant's belief system, there is no more need to delve into the question of sincerity. No manifestation

\footnotetext{
${ }^{33}$ A few prominent examples: Commission decision 12 June 1979, No. 7050/75, Arrowsmith v The United Kingdom (handing out leaflets to British soldiers that criticise British policy in Northern Ireland is not a manifestation of Pacifism); Dv France, supra n. 13 (refusing the get is not a manifestation of Orthodox Judaism); ECtHR 18 December 1996, No. 24095/94, Efstratiou v Greece (refusing to participate in a school-mandated parade commemorating the outbreak of war between Greece and Fascist Italy is not a manifestation of the Pacifist convictions of school students who are Jehovah's Witnesses).

${ }^{34} \mathrm{Su}$, supra n. 21, writes that there is a 'discernible Western judicial consensus' that freedom of belief protects whatever 'belief the individual sincerely claims to believe, regardless of its [...] basis on objective religious text or doctrine' (p. 30). She includes the Court in this consensus because she believes Eweida (ECtHR 15 January 2013, No. 48420/10, Eweida and others $\mathrm{v}$ The United Kingdom) is a 'clear break from [the Court's] previous pronouncements that not every act motivated or inspired by a religion or belief' falls under the protection of Article 9 (p. 36). Su is surely mistaken here. In Eweida, the Court does state for the first time, in para. 82, that applicants do not have to show that a practice concerns a duty within their belief system. The Court also states that manifestations are not limited to acts of worship or devotion. But in the same section, it repeats what it has said in Skugar and other cases: 'it cannot be said that every act which is in some way inspired, motivated or influenced by it constitutes a "manifestation" of the belief. Thus, for example, acts or omissions which do not directly express the belief concerned or which are only remotely connected to a precept of faith fall outside the protection of Article 9' (emphasis added). In a number of subsequent cases - S.A.S. v France, supra n. 20, among them - the Court repeats that Art. 9 does not 'protect every act motivated or inspired by a religion or belief'.
} 
means no protection under freedom of belief. ${ }^{35}$ It does not matter whether or not $\mathrm{D}$ truly believes that refusing to provide the get is a manifestation of his religion. Since the Court has found that it is not, the refusal is not legally a religious practice, and therefore the matter is not covered by freedom of belief - case closed.

In short, Chapman is correct about it not being part of a court's job to infer insincerity from the implausibility of a purported manifestation. But for reasons other than the no-orthodoxy principle, which in my view is untenable in its extreme form.

\section{Inconsistency with beliefs of co-believers}

Suppose a belief an individual wishes to practise is not shared by fellow adherents and/or official organs of her belief system. Does this provide reason to suspect that she is a fake practitioner - someone who is insincere about the practice being a manifestation of the belief system? (Like 'implausible manifestation', the circumstance 'inconsistency with beliefs of co-believers' is linked to type (c) insincerity.) Suppose a Muslim woman claims her religion requires her to cover her body in public and that a niqab or burqa is not sufficient because those garments still somewhat reveal the contours of the hips, the backside, and so on. What women really must wear in public, she maintains, is an oblong cardboard box that is open on the underside to allow for walking. Presumably, no fellow Muslims and no Muslim authorities (imams, Islamic Universities, etc.) would endorse this belief. Would this, by itself, be a reason to doubt her sincerity? I would think not. As explained in the previous subsection, it is up for judicial debate whether the practice of wearing such a box should be recognised as a manifestation. But that debate would be focused on the Manifestation Condition, which is a separate matter. If it were decided that wearing the cardboard box is not a manifestation of Islam, the question of sincerity would be rendered moot. However, if the practice were recognised as a manifestation, I do not see why its unusualness would cast doubt on the woman's sincerity. Chapman is correct in tolerating religious atomism.

Paradoxically, Chapman simultaneously defends the legitimacy of 'inconsistency with beliefs of co-believers' as a credibility-undermining circumstance, calling it 'community-fit evidence'. He writes: 'I suggest that courts should also consider evidence about whether the claimant's alleged religious beliefs fit with the beliefs of the claimant's religious community'. ${ }^{36}$ Chapman's stance on this matter

\footnotetext{
${ }^{35}$ This point presupposes what has been mentioned earlier, that it is logical to examine the three conditions in the order in which I stated them, namely: Belief System Condition > Manifestation Condition $>$ Sincerity Condition.

${ }^{36}$ Chapman, supra n. 14, p. 1237.
} 
is cautious, though. Community-fit evidence, he emphasises, should only be allowed to supplement ulterior motive and/or inconsistency evidence. It cannot by itself support a finding of insincerity. Still, weight is being attached to beliefs of co-believers in the assessment of sincerity. This seems wrong. To return to the cardboard box example, a judge might find it strange that the claimant is the only one of her religious community to believe that the box is one of its manifestations. But eccentrics can be just as sincere as conformists. Letting the appraisal of the woman's sincerity depend on how the rest of the Ummah feels about the box would amount to a denial of this simple truth.

The case law of the Court sometimes refers to beliefs of co-believers. In $D$ v France, it was noted that 'the applicant would seem to be at variance on this point with the religious leaders under whose authority he claims to be acting. ${ }^{37}$ Here, however, the Commission was clearly talking about whether refusing the get is a practice of Orthodox Judaism (i.e. the Manifestation Condition). The argument did not involve invoking community-fit evidence to assess sincerity. The same goes for the Court's reasoning in Skugar:

In the instant case the interpretation of the Bible to which the applicants adhere appears to be at variance with the position expressed by the Holy Synod of the Russian Orthodox Church in its statement of 7 March 2000. However, in the absence of any indication of insincerity on the part of the applicants, the Court accepts that their rejection of technologically-derived markers for religious reasons may, in principle, qualify for protection under Article 9 of the Convention. ${ }^{38}$

Clearly - and rightly - lack of community-fit was not viewed as a reason to question the claimant's sincerity, in either D v France or Skugar.

S.A.S., as we have seen, is different. In that case, the presence of community-fit (some Muslim women prefer the full face veil) was put forward as evidence of the claimant's sincerity. I have argued above that this is unsound. The general lesson should be that neither consistency nor inconsistency with beliefs of co-believers should be seen as having any clear bearing on sincerity. Consistency with beliefs of co-believers says little about the sincerity of the claimant because she may just be mimicking true believers' behaviours in order to pass herself off as one of them. Equally little can be deduced from inconsistency with beliefs of co-believers, since eccentricity does not imply insincerity (nor does it imply sincerity).

Let us recapitulate. Two candidates for credibility-undermining circumstance have thus far been examined: 'implausible manifestation' and 'inconsistency with

${ }^{37} \mathrm{D}$ v France, supra n. 13, s. 2.

${ }^{38}$ Skugar v Russia, supra n. 16. This passage is ambiguous in that it is also consistent with the strictly supplementary role Chapman ascribes to 'community-fit evidence'. 
beliefs of co-believers'. Both failed to make the grade. Next in line are three candidates that will: 'obvious unseriousness of the belief system', 'ignorance regarding the belief system', and 'personal inconsistency'.

\section{Obvious unseriousness of the belief system}

'Obvious unseriousness' is a fairly straightforward circumstance that is relevant to parody belief systems (type (a) insincerity). By 'obviously unserious', I mean jokey, droll, or light-hearted. Thus, mentioning a 'beer volcano', the 'Olive Garden of Eden', and a 'stripper factory', as does the Gospel of the Church of the Flying Spaghetti Monster, or declaring that laundry rooms are shrines to a divine, invisible pink unicorn and that holes in socks have been made by that deity, as 'followers' of the Church of the Invisible Pink Unicorn do, will obviously raise questions about seriousness and, therefore, about sincerity.

Readers may wonder: if the premise of parody belief systems is tongue in cheek, why do many 'adherents' - at least ostensibly - maintain a posture of seriousness in court? This can be explained by the fact that most 'adherents' of parody belief systems are principled in the same way as are the people who created the parodies. For example, 'Pastafarians' who engage in litigation presumably intend to engender debate about and attract attention to their cause. Keeping a straight face in litigation can be seen as a way of staying in character for the sake of getting the message out. ${ }^{39}$

Parody belief systems constitute one of the two subspecies of fake belief system, while fraudulent belief systems constitute the other. Of the two, parody belief systems tend to be very obviously unserious since, again, those who create parody religions intend to make a political point in a satirical manner. It is in their interest to be whimsical, stand out, and draw attention to themselves. But detecting the unseriousness of fraudulent belief systems might be more difficult since

\footnotetext{
${ }^{39}$ The claimant in the aforementioned Dutch Pastafarianism case has decided to go on keeping a straight face in her dealings with news media. For instance, in a YouTube interview, she claims to actually believe in the existence of the Flying Spaghetti Monster, and she adds that the humour of Pastafarianism is but a matter of style: 〈https://youtu.be/LuuF4RE84II?t=208〉, visited 15 June 2021. Some 'adherents' of obvious parody belief systems may not be principled in this way. For instance Chapman, supra n. 14, p. 1216, cites a case of a prisoner who claimed adherence to Pastafarianism and asked for large bowls of pasta. Perhaps the fake belief system in such a case should be seen not as a parody belief system, but as a fraudulent one. This perhaps shows that the nature of a fake belief system depends on the claimant's motive. If the motive is to secure a material advantage, a 'belief system' that should be considered a parody in 'standard' cases should in such a case be conceptualised as a fraudulent one.
} 
they tend to not be obviously unserious. Fraudsters have an incentive to appear serious and not make too many waves. ${ }^{40}$ As Jarret Field writes:

What if the deliberately outlandish were replaced by a perfectly plausible, albeit manufactured, belief system? What if the humor present in Pastafarianism, susceptible to a federal judge's 'basic reading comprehension', were stripped away, and we were left with a belief system imperceptibly similar to major organized religions that regularly secure religious exemptions and accommodations? How could a court of law pierce the veil of a well-developed invented religion to determine whether a claim has merit? ${ }^{41}$

This kind of non-obvious unseriousness is an important concern - one which courts will have to address should the occasion arise. To answer Field's last question, other suspicious circumstances would need to be present, such as behavioural inconsistencies. Nevertheless, I believe he is correct in that it is at least conceivable that an imperviable ruse may be created (perhaps one already has been; for all we know, some recognised belief systems are long cons ${ }^{42}$ ).

What is the Court's attitude towards parody belief systems? This is difficult to answer since it has unfortunately never adjudicated a case involving a parody belief system (to my knowledge). However, the woman of the Dutch Pastafarianism case has announced her intention to bring her case before the Court. ${ }^{43}$ My prediction would be that the Court will make short shrift of such an attempt to invoke Article 9 to gain legal protection for a parody belief system. As mentioned earlier, the Court, by way of its 'seriousness' criterion for 'belief', has incorporated a sincerity requirement of sorts into its test for (what I have

\footnotetext{
${ }^{40}$ Remarkably, some almost certainly fraudulent belief systems choose to formulate tenets that are quite obviously unserious. For example, the First Church of Cannabis is almost certainly designed to allow its members to consume marijuana with impunity. Yet some of the Church's guidelines ('The Deity Dozen') seem quite parody-like: 'Don't be an asshole' and 'Do not be a "troll" on the internet', J.S. Newman, 'What is a Church? A Look at Tax Exemptions for the Original Kleptonian Neo-American Church and the First Church of Cannabis', 4 Lexis Federal Tax Journal Quarterly (2015). Perhaps such 'belief systems' should be seen as a parody-fraud hybrid, or perhaps the people involved do not fully understand that sincerity is a requirement of a successful appeal to freedom of belief (see Chapman, supra n. 14, p. 1187, who contends that some judges -including U.S. Supreme Court justices - are confused in the same way with regard to the sincerity requirement).

${ }^{41} \mathrm{~J}$. Field, 'Guise of Belief: Acquiring Religious Accommodations with an Invented Religion and a Veil of Religious Sincerity', Cornell Journal of Law \& Public Policy (online), 25 September 2018, 〈http://jlpp.org/blogzine/guise-of-belief-acquiring-religious-accommodations-with-an-invented-religionand-a-veil-of-religious-sincerity/ $\rangle$, visited 15 June 2021.

${ }^{42} C f$ Newman, supra n. 40 (arguing that the risk that an occasional illegitimate organisation might derive benefits from being recognised as a religious group is an acceptable price to pay for a robust First Amendment).

${ }^{43} \mathrm{See}$ 〈www.voxweb.nl/nieuws/eindejaarsvragen-1-pastafarier-mienke-de-wilde〉, visited 15 June 2021.
} 
termed) the Belief System Condition. I suspect that this requirement should be perceived at least in part as designed to rule out fake belief systems. Given the way the Sincerity Condition and the Belief System Condition overlap in these sorts of cases, the implication of the Court finding type (a) insincerity (in the Court's terminology: the absence of a certain level of seriousness) would be that there is no belief within the meaning of Article 9.

It should be noted that the criterion of obvious unseriousness is not meant to exclude unusual, idiosyncratic, new, and marginal belief systems. If anything, those systems perhaps need more legal protection than do major, established belief systems. Neither does it entail any assessment of the plausibility or accuracy of belief systems. It is true that the (ostensible) propositional content of parody belief systems is implausible, to put it mildly, but then again, so too is the propositional content of many very serious belief systems. So it is important to emphasise that parody belief systems are excluded not due to their implausibility, but due to their unseriousness, which - due to its obviousness - is easy to detect (unlike the unseriousness of well-crafted fraudulent belief systems).

\section{Ignorance regarding the belief system}

Ignorance regarding a professed belief system is obviously a legitimate credibilityundermining circumstance and thus evidence of insincerity. An individual who cannot explain what Zoroastrianism holds true and entails does not make a very convincing Zoroastrian. This type of circumstance is relevant in the context of type (b) insincerity (fake adherence). An 'adherent' who is unable to describe any aspect of her professed belief system is evidently a fraud. This does not imply that a claimant must be able to describe and explain every single aspect of it. Recall that a belief system was described as a set of connected propositions that one or more persons believe to be true to some minimal degree and that belief systems may be practised in a primarily ritualistic or communitarian fashion. An individual can be ignorant of many doctrinal aspects of a belief system and still be a genuine adherent. So even though testing knowledge is an appropriate strategy for detecting and assessing this type of insincerity, it comes with caveats.

An interesting account of the pitfalls of knowledge testing can be found in a document from the United Nations High Commissioner for Refugees (UNHCR). ${ }^{44}$ As noted earlier, an important class of fake adherents are asylum

\footnotetext{
${ }^{44}$ UNHCR, 'Guidelines on International Protection: Religion-Based Refugee Claims Under Article 1A(2) of the 1951 Convention and/or the 1967 Protocol Relating to the Status of Refugees' (2004) 〈www.unhcr.org/publications/legal/40d8427a4/guidelines-international-protection-6-religion-basedrefugee-claims-under.html $\rangle$, visited 15 June 2021. See also Norman, supra n. 12 and Sweeney, supra n. 12.
} 
seekers who falsely claim to be adherents of persecuted belief systems. It is this issue that the UNHCR addresses. The document provides a set of guidelines for the assessment of religion-based refugee claims, based on experiences of immigration officials. Several aspects of these guidelines are pertinent to the present discussion.

First, courts can only properly evaluate answers to knowledge-related questions if they know the correct answers. But major religions and philosophies of life are not monolithic. Beliefs and practices may vary across regions and sects, hence the need for, as the UNHCR writes, 'reliable, accurate, up-to-date, and country- or region-specific as well as branch or sect-specific information'. ${ }^{45}$ Of course, if a selfprofessed 'adherent' is unable to formulate any answer to even the most basic questions, courts can certainly draw their conclusions from that without needing to know the correct answers themselves. In Kosteski v Macedonia, the case about the man who justified his absence from work on an Islamic holiday by claiming to be a Muslim, Kosteski made some statements during the proceedings before the Constitutional Court of Macedonia that demonstrated, in the words of that court, a lack of knowledge of the basic most important tenets of the religion through which its essence is expressed ... or of the way in which one "joins" the Muslim faith, etc' ${ }^{46}$ The (Strasbourg) Court did not directly base its decision (that fining Kosteski for his absence from work was not a violation of Article 9) on this ignorance; it based it on the fact that the applicant had (largely) refused to corroborate his claim of adherence to Islam. The Court did state, however, that one reason why the Macedonian government's demand that the applicant provide evidence was not unreasonable was that Kosteski made his claims 'in circumstances which arguably gave rise to doubts as to his entitlement ${ }^{4}{ }^{47}$ To the extent that the Court was referring to the findings of the Constitutional Court concerning Kosteski's ignorance, it appeared to sanction ignorance as legitimate evidence of insincerity.

A second insight found in the UNHCR guidelines is that knowledge of belief systems may vary depending on class, education, and sex. Some adherents' belief systems may be more of an identity or way of life than a conscious conviction that certain propositions are true. They should not be expected to be able to answer questions about specific doctrines or holy texts. This point should only be taken so far, though. Even unreflective believers should be able to describe certain basic tenets, values, and practices - something Kosteski was unable to do. Nevertheless, it is worth keeping in mind that, as the UNHCR points out, descriptions of the individual's belief system are more likely to be forthcoming

\footnotetext{
${ }^{45}$ Ibid, p. 10.

${ }^{46}$ Kosteski v The Former Yugoslav Republic of Macedonia, supra n. 9, para. 23.

${ }^{47}$ Ibid, para. 46.
} 
if narrative forms of questioning are used - that is, no demands, or not only the demand, to list the 'Ten Commandments or name the Twelve Imams', but requests for information regarding the individual's identity or way of life: 'open-ended questions allowing the claimant to explain the personal significance of the religion to him or her' and 'the practices he or she has engaged in ... '48 In Vartic v Romania, the Court's approach appears to be along these lines. The Romanian government was sceptical of prisoner Vartic's purported adherence to Buddhism, partly because of a suspected ulterior motive for his wish to receive nonstandard prison food. In response, the Court argued that Vartic 'provided a coherent account of the manner in which he observed his Buddhist faith' ${ }^{49}$

The final point worth noting is that using this narrative form of questioning rather than a facts-and-figures approach not only helps to prevent false negatives (i.e. incorrectly labelling someone a fake adherent), but also helps prevent false positives (i.e. incorrectly labelling someone a genuine adherent). Many cases of fake adherence involve a purported conversion. For a 'convenience-convert', as they are called, who has been prepping to deceive the authorities, it may be easy to rattle off the Ten Commandments or the Twelve Imams. In such cases, the UNHCR writes, testing facts-and-figures knowledge is again of limited value. Instead, 'the interviewer needs to ask open questions and try to elicit the motivations for conversion and what effect the conversion has had on the claimant's life. ${ }^{50}$ These do seem like questions for which rehearsing the 'right' answers is difficult. Presumably, assessing the claimant's demeanour and poise during questioning also comes into play here. ${ }^{51}$

\section{Personal inconsistency}

'Personal inconsistency' concerns behaviour which is inconsistent with the beliefs the individual claims to hold. It is relevant in the contexts of all three types of insincerity. There is no doubt that personal inconsistency is a legitimate credibility-undermining circumstance, and it is front and centre in every

${ }^{48}$ UNHCR, supra n. 44, p. 11.

${ }^{49}$ Vartic v Romania, supra n. 11, para. 46.

${ }^{50} \mathrm{UNHCR}$, supra n. 44, p. 12.

${ }^{51}$ That ignorance is especially relevant to the problem of fake adherents is not to say that all fake adherents are lacking in knowledge, either of the facts-and-figures variety or the narrative variety. Apostates who were previously lifelong adherents are not at all ignorant with respect to their former belief systems, and yet they may pretend to still be adherents for one reason or another. It would seem that demeanour during questioning would become an important factor in such cases (as well as other suspicious circumstances, such as inconsistent behaviour). 
article on sincerity of belief. ${ }^{52}$ The basic idea is straightforward: a person is not believable unless she practises what she preaches. For example, it would be quite unconvincing if someone were to show up in court bareheaded to plead the case that her belief system requires her to always wear a colander in public. Although the basic idea is simple, the devil is in the detail. Just as, as we have seen, some degree of ignorance regarding one's belief system is consistent with sincerity, so some forms of inconsistency are acceptable. Furthermore, not everything that appears inconsistent actually is. To shed some light on these complexities, I once again distinguish three main categories:

- pseudo-inconsistency;

- acceptable inconsistency;

- unacceptable inconsistency.

\section{Pseudo-inconsistency}

Lowentheil and Platt mention an American case about a conscientious objector to military service. ${ }^{53}$ The man claimed to be a Jehovah's Witness and had stated that military service was incompatible with the pacifistic doctrines of his faith. One reason he was deemed insincere was that he had repeatedly beaten his wife. At first glance, this seems correct (the deeming, not the beating). Not wanting to participate in violence does not seem very convincing coming from a known assaulter. But on second thought, I am not so sure. Jehovah's Witnesses typically object to military service because the Bible claims 'Nation will not lift up sword against nation' (Isaiah 2:4). As reprehensible as domestic abuse obviously is, it does not necessarily seem inconsistent with this principle. More generally, I would maintain that the allegedly inconsistent behaviour must be approximately on the same plane as the stated belief (and corresponding practice) in order for there to be real inconsistency. If not, the behaviour provides no reason to suspect or surmise insincerity.

Another form of pseudo-inconsistency occurs when the claimant's actions are at variance with a strict version of her belief system, while she herself adheres to a more liberal version. Thus, working on a Sunday does not necessarily make a selfproclaimed Christian a fake adherent, because her articulated beliefs concerning the sabbath may not be very strict. It is a different story, of course, if she makes a legal demand to be exempted from working on Sundays, which would clearly

\footnotetext{
${ }^{52}$ S. Senn, 'The Prosecution of Religious Fraud', 17 Florida State University Law Review (1990) p. 325; A. Hambler, 'Establishing Sincerity in Religion and Belief Claims: A Question of Consistency', 13(2) Ecclesiastical Law Society (2011) p.146; Adams and Barmore, supra n. 23; Su, supra n. 21; Chapman, supra n. 14; Loewentheil and Reiner Platt, supra n. 24.

${ }^{53}$ Lowentheil and Platt, supra n. 24, p. 253.
} 
imply strictness on the subject of the sabbath. In that case her working on Sundays would, absent a reasonable explanation (see below), be an indication of fake practitionership or even fake adherence.

I suppose $W \mathrm{v}$ The United Kingdom, the case involving a vegan prisoner who refused to work in the prison print shop, also involved a form of pseudoinconsistency. ${ }^{54}$ The British government claimed that $\mathrm{W}$ had acted inconsistently by failing to mention his vegan beliefs in disciplinary prison proceedings concerning the print shop dispute. The Commission, however, argued that this negligence could not be held against him because he had 'expressly invoked the requirements of his Vegan beliefs in written complaints to the prison authorities before and contemporaneously with the disciplinary proceedings'. ${ }^{55}$

\section{Acceptable inconsistency}

Some behaviours (including utterances and written words) are inconsistent with a stated belief but do not vitiate sincerity because they may be reasonably explained. One such explanation is formal or informal social pressure. Acting against one's belief because the government or some other authority forces one to do so does not make one insincere. Lowentheil and Platt cite a case in which a school board claimed an employee's religious beliefs were insincere because he refrained from certain religious practices. But the school board's own policy had forbidden him to do otherwise. ${ }^{56}$ Hambler discusses the example of a civil servant who cited a religious reason for not wanting to assist a homosexual couple in an adoption procedure. The civil servant was suspected of insincerity because he only filed the religious objection after a 'neutral' objection was rejected. He explained that, given what he considered to be a highly politically correct social climate, he had feared the social repercussions of revealing his religious misgivings. ${ }^{57}$

Another reasonable explanation for inconsistency is conversion. ${ }^{58}$ Suppose an individual converts to Judaism. Chances are that she has engaged in some unkosher behaviour prior to the conversion, such as consuming pork. Such past behaviour obviously does not impugn the conversion's genuineness - not even if the same practice is at stake in the legal dispute. If a prisoner claims to have converted to Judaism and asks to be served a kosher diet, the fact that she has been known to eat pork in the past should not by itself cast doubt on her sincerity. Nevertheless, convenience converts do exist and can be detected through

${ }^{54} W \mathrm{v}$ The United Kingdom, supra, n. 11.

${ }^{55}$ Ibid, para. 1.

${ }^{56}$ Lowentheil and Platt, supra n. 24, p. 254.

${ }^{57}$ Hambler, supra n. 52, p. 154.

${ }^{58}$ Hambler, supra n. 52, p. 54; Chapman, supra n. 14, p. 1235; Lowentheil and Platt, supra n. 24, p. 277. 
suspicious circumstances (e.g. ignorance regarding the belief system) as well as through inconsistent behaviour (e.g. eating pork after the supposed conversion) or inconsistent statements (for example, the claimant has told a witness 'don't tell anyone, but I'm faking this Judaism thing to get better food'). The timing of a conversion may be suspicious as well. An asylum seeker who has converted to a persecuted belief system shortly before requesting asylum should be given more scrutiny than one who has actually been persecuted for years as a member of that belief system.

Moral failing can also provide a reasonable explanation for inconsistency. ${ }^{59}$ Generally speaking, and particularly with very demanding belief systems, failure to always act according to a belief system's precepts does not necessarily vitiate sincerity. No one is perfect, some people are weak-willed, and so on. These exceptions somewhat complicate matters because, for instance, even eating pork after a supposed conversion may be attributed to moral backsliding. Inconsistent behaviour, it seems, must be consistent to some extent to legitimately undermine the claimant's credibility; or be supplemented by further suspicious circumstances, such as inconsistent statements (like the one about better food) or ignorance regarding the belief system.

\section{Unacceptable inconsistency}

Unacceptable inconsistency may be described in terms of the foregoing: it is any real (as opposed to pseudo-) inconsistency for which there is no reasonable explanation. For example, Kosteski had no reasonable explanation for why he actively celebrated Christian holidays during the period when he also demanded leave on Islamic holidays; for why he had not identified as a Muslim on his employment and insurance papers; or for why his diet and way of life indicated the Christian faith. By contrast, in Kovalkovs v Latvia, Kovalkovs was accused by the Latvian government of being a fake adherent of Vaishnavism because he had participated in a Bible study course. But clearly, taking the course does not even amount to pseudo-inconsistency - let alone real inconsistency or unacceptable real inconsistency. As the Court rightly argued, 'in no way can a person's choice to educate himself - be it on religious or other topics - be objectively held to affect that person's belief system'. ${ }^{60}$

S.A.S. is more ambiguous, as the applicant in that case did not wear the full face veil consistently: 'she might not wear it, for example, when she visited the doctor, when meeting friends in a public place, or when she wanted to socialise in public'. She 'wished to be able to wear it when she chose to do so, depending in

\footnotetext{
${ }^{59}$ Greenawalt, supra n. 3, p. 121; Hambler, supra n. 52, p. 155; Chapman, supra n. 14, p. 1235; Lowentheil and Platt, supra n. 24, p. 277.

${ }^{60}$ Kovalkovs v Latvia, supra n. 11, para. 57.
} 
particular on her spiritual feelings', and accordingly, '[ $t$ ]here were certain times (for example, during religious events such as Ramadan) when she believed that she ought to wear it in public in order to express her religious, personal and cultural faith'. ${ }^{61}$ Surprisingly, the Court did not address the issue of inconsistency even though the French government had strongly emphasised it. What should have been the conclusion if the Court had addressed it? It does seem hard to swallow, at first glance, that a belief (the belief concerning the veil) that is associated with extreme strictness should be practised so loosely. On the other hand, what is so strange about an individual whose personal faith involves wearing certain religious garments only on certain occasions? Such a circumstance is analogous to a Christian who does not mind working on Sundays but does mind working on Easter Sunday or a Jew who only wishes to wear the yarmulke on Jewish holy days. In short, I would classify the behaviour of the woman in S.A.S. as a case of pseudo-inconsistency.

\section{ON BURDEN OF PROOF}

As mentioned in the Introduction, a case law guide on the Court's website states that 'domestic authorities are not justified in casting doubt on the sincerity of the beliefs which an individual claims to hold without supporting their position with solid, cogent evidence. ${ }^{62}$ In the previous section we have talked about which circumstances ought to count as solid, cogent evidence. As to the division of evidentiary labour, the case law guide suggests that the burden of proof belongs to the domestic authorities: the claimant does not need to prove she is sincere, the authorities need to prove she is not. (Recall the point from footnote 2: insincerely invoking freedom of belief is an offence of sorts. Hence the focus in the literature on evidence of insincerity.) In the Court's decisions concerning (in)sincerity this view on burden of proof is seldom stated in so many words. But, as we have seen, domestic authorities in these cases do indeed provide evidence of insincerity. And in several instances the Court deems the evidence they provide irrelevant or insufficient, even when the applicant has provided no counter-evidence. In this sense the view on burden of proof set out in the case law guide is borne out by the actual case law.

There is one complication. In cases of conscientious objection and in the field of employment the Court considers it compatible with Article 9 for governments or employers to require claimants to provide proof of their sincerity. This is because these cases typically concern exemptions of the sort that put burdens on others and involve considerable privileges for the exempted. Thus, escaping

${ }^{61}$ S.A.S. v France, supra n. 20, all quotations from para. 12.

${ }^{62}$ Directorate of the Jurisconsult, supra n. 1, p. 12. 
a general duty to perform military service means you will not have to risk life and limb, while someone else has to take your place. Getting extra days of paid leave from work is a substantial benefit for the employee as well as a financial burden on the employer. Thus, in Kosteski the Court stated:

the Court does not find it unreasonable that an employer may regard absence without permission or apparent justification as a disciplinary matter. Where the employee then seeks to rely on a particular exemption, it is not oppressive or in fundamental conflict with freedom of conscience to require some level of substantiation when that claim concerns a privilege or entitlement not commonly available and, if that substantiation is not forthcoming, to reach a negative conclusion. ${ }^{63}$

This seems sound. Somewhat harder to understand is why this should not apply to other areas where special privileges are at stake that are burdensome to others. For example, in the prisoner case Kovalkovs v Latvia ${ }^{64}$ the Court seems to take the claimant's statements concerning his adherence to Vaishnavism almost at face value. But, as the Court itself argues elsewhere in that decision, the special privileges that prisoner Kovalkovs demanded were burdensome for others. Perhaps this has to do with the fact that the domestic authorities had not required the claimant to substantiate his motives, as a result of which the Court had to make do with the limited information available from the domestic procedures. Although the Court is authorised to 'adopt any investigative measure which it considers capable of clarifying the facts of the case' (Rule A1 Investigative measures, Rules of Court ECHR), it seldom does.

At any rate, it is clear that in some circumstances the claimant is required to substantiate her claims concerning her belief(s). This may be done by pointing out the opposites of the credibility-undermining circumstances we have been discussing; credibility-enhancing circumstances, if you will. Thus, if Kosteski had been able to show that he had been celebrating Islamic holidays for years (the opposite of personal inconsistency) and that he had knowledge of the basic tenets and values of Islam (the opposite of ignorance regarding the belief system), he probably would have convinced the domestic authorities of his adherence to Islam. With respect to ulterior motive, a claimant can dispel doubts by showing that he is or has been prepared to forgo benefits rather than compromise his beliefs. For example, a claimant who has shown that he is prepared to lose his job rather than shave his beard, or go without food altogether rather than eat non-kosher prison food, is more likely to be deemed sincere. ${ }^{65}$ Similarly, a conscientious

\footnotetext{
${ }^{63}$ Kosteski v The Former Yugoslav Republic of Macedonia, supra n. 9, para. 39.

${ }^{64}$ Kovalkovs v Latvia, supra n. 11, para. 57.

${ }^{65} \mathrm{Cf}$ Loewentheil and Platt, supra n. 24, p. 257.
} 
objector to military service can demonstrate his bona fides by offering to perform alternative community service. ${ }^{66}$

\section{Conclusion}

Insincerity occurs when an individual demands to practise her 'belief' while solely having an ulterior motive. A claimant who has no sufficiently likely ulterior motive (as in Skugar and S.A.S.) should in most circumstances ${ }^{67}$ be presumed to have no ulterior motive and should therefore be deemed sincere. The Court has never explicitly applied this principle, although, as we have seen, Skugar can be read as an implicit espousal of it. If there is a sufficiently likely ulterior motive, three types of circumstance can indicate and help prove the presence of ulterior-motive-solely and, therefore, insincerity:

- obvious unseriousness of the belief system (as in parodies);

- ignorance regarding the belief system (more precisely, unacceptable - i.e. too much - ignorance regarding the belief system); and

- personal inconsistency (more precisely, unacceptable - i.e. lacking a reasonable explanation - personal inconsistency).

With regard to 'obvious unseriousness': if a 'belief system' is obviously unserious (e.g. Pastafarianism, Church of the Pink Unicorn), the claimant should be presumed to have solely an ulterior motive and should therefore be deemed insincere. $^{68}$ The Court has not yet had cause to directly address this issue. With regard to 'ignorance regarding the belief system': if a claimant is unable to sufficiently explain 'her' belief system, she should be presumed to have solely an ulterior motive and should therefore be deemed insincere. ${ }^{69}$ The Court has arguably endorsed this principle in both Kosteski and Vartic. With regard to

${ }^{66}$ Which was what the applicant in ECtHR 7 July 2011, No. 23459/03, Bayatyan v Armenia, a Jehovah's Witness, did repeatedly. But see also Commission decision 11 October 1984, No. 10410/83, $N \mathrm{v}$ Sweden, which seems to show that not being prepared to perform alternative service does not necessarily entail ulterior motive. As the applicant in that case wrote, 'The non-armed service of today is a substitute for military service. To accept non-armed service thus implies acceptance of the principle of liability to military service. I do not accept that the State has any "right" to draft me or others for education in the technique of mass murder'. It should be noted that not all beliefs and practices are amenable to trade-offs like these. See Hambler, supra n. 52, p. 151.

${ }^{67}$ Unless there is glaringly obvious unacceptable ignorance or personal inconsistency. This would indicate bizarre and improbable but possible motives.

${ }^{68}$ That is, insincere about the existence of the 'belief system', so type (a) insincerity. Recall that, in many jurisdictions, 'seriousness' (or some equivalent concept) is an element of the legal definition of 'belief system' (or some equivalent concept).

${ }^{69}$ That is, insincere about her adherence to the belief system, so type (b) insincerity. 
'personal inconsistency': if a claimant has acted or spoken in a way that is inconsistent with her stated belief(s) and her actions cannot be explained by social pressure, conversion, or moral failure, she should be presumed to have solely an ulterior motive and should therefore be deemed insincere. ${ }^{70}$ The Court has endorsed a version of this principle in $W \mathrm{v}$ The United Kingdom, Kosteski, and Kovalkovs. Of course, if more than one of these circumstances is present, the case becomes even stronger (e.g. Kosteski was both ignorant and inconsistent).

The other two candidates that have been examined - 'implausible manifestation' and 'inconsistency with beliefs of co-believers' - should not be considered indicators or evidence of insincerity (it is therefore unfortunate that in S.A.S. the Court appeared indirectly to endorse 'implausible manifestation' and 'inconsistency with beliefs of co-believers' as indicators of insincerity). As we have seen, manifestation implausibility renders the question of sincerity moot, and religious or philosophical atomism is possible and acceptable such that inconsistency with beliefs of co-believers has no clear bearing on the sincerity of the atomist in question.

\footnotetext{
${ }^{70}$ That is, insincere about the existence of the 'belief system', about her adherence to a belief system, or about a practice being a manifestation of a belief system; thus, type (a), (b), and/or (c).
} 